\title{
ANALISIS DAYA SAING DAN DAMPAK KEBIJAKAN PEMERINTAH TERHADAP KOMODITAS TEH (STUDI KASUS: PTPN VIII AFDELING RANCABALI III)
}

\author{
Palupi Permata Rahmi ${ }^{1)}$, Rr. Heny Kuswanti Suwarsinah ${ }^{2)}$ dan Ratna Winandi ${ }^{2)}$ \\ ${ }^{1,2,3)}$ Magister Sains Agribisnis, Fakultas Ekonomi dan Manajemen, Institut Pertanian Bogor \\ ${ }^{1)}$ palupipermata@yahoo.com
}

\begin{abstract}
Rancabali III department, National Plantation VIII produces tea with national and international standard of quality. The purpose of this study are to analyze the effect of government policies, increase of output price, increase of chemical fertilizer price, and production number decline to orthodox black tea competitiveness at Rancabali III department, National Plantation VIII. The methods are Policy Analysis Matrix and sensitivity analysis. The result shows that government policies, output price, chemical fertilizer price and production number affect the competitiveness of orthodox black tea at Rancabali III department National Plantation VIII..
\end{abstract}

Keyword(s): orthodox black tea, competitiveness, policy analysis matrix (PAM)

\begin{abstract}
ABSTRAK
PTPN VIII Afdeling Rancabali III menghasilkan komoditas teh dengan standar kualitas nasional dan internasional. Tujuan dari penelitian ini yaitu menganalisa pengaruh kebijakan pemerintah, peningkatan harga output, peningkatan harga pupuk anorganik serta penurunan produksi terhadap daya saing teh hitam orthodoks pada PTPN VIII Afdeling Rancabali III. Metode yang digunakan adalah Matriks Analisis Kebijakan dan analisis sensitivitas. Hasil analisis menunjukkan bahwa bahwa kebijakan pemerintah, harga output, harga pupuk anorganik dan jumlah produksi teh hitam orthodoks mempengaruhi daya saing usahatani teh hitam orthodoks di PTPN VIII Afdeling Rancabali III.
\end{abstract}

Kata Kunci: teh hitam orthodoks, daya saing, Matriks Analisis Kebijakan (PAM)

\section{PENDAHULUAN}

Sektor pertanian mempunyai peranan yang cukup penting dalam kegiatan perekonomian di Indonesia, hal ini dapat dilihat dari kontrribusinya terhadap Produk Domestik Bruto yang cukup besar yaitu sekitar 14,44 persen pada tahun 2012, menempati posisi kedua setelah sektor industri pengolahan (BPS, 2013).

Salah satu sub sektor pertanian yang cukup besar potensinya adalah sub sektor perkebunan, meskipun kontribusi sub sektor perkebunan belum terlalu besar yaitu sekitar 1,94 persen, atau berada pada urutan ketiga di sektor pertanian setelah sub sektor tanaman pangan dan perikanan, namun sub sektor perkebunan merupakan penyedia bahan baku untuk sektor industri, penyerap tenaga kerja, dan penghasil devisa negara (BPS, 2013)

Sub sektor perkebunan Indonesia memiliki beberapa komoditi yang menjadi andalan yakni karet, minyak 
sawit, kopi, kakao, teh, kina, tebu dan tembakau. Komoditas teh merupakan salah satu komoditas ekspor unggulan yang dimiliki oleh Indonesia. Hal ini dibuktikan dari kontribusi komoditas teh terhadap Indonesia yaitu menyumbang devisa negara sebesar US\$ 156.741 .000 pada tahun 2012 (BPS, 2013).

Indonesia menempati peringkat ketujuh sebagai negara produsen teh terbesar di dunia setelah China, India, Kenya, Sri Lanka, Turki, dan Vietnam dengan produksi sebesar 119.651 ton pada tahun 2011 (BPS, 2013). Perkembangan volume ekspor teh mengalami penurunan dari US\$ 158.959 .000 pada tahun 2008 menjadi US\$ 156.741 .000 pada tahun 2012 (BPS, 2013). Dalam hal produksi, produksi teh di Indonesia cenderung menurun yaitu dari 153.282 ton pada tahun 2008 menjadi 150.127 ton pada tahun 2012. Teh di Indonesia diproduksi oleh perkebunan rakyat, perkebunan negara, dan perkebunan swasta. Perkebunan milik negara merupakan perkebunan penyumbang produksi teh terbesar di Indonesia yaitu sebesar 40,98 persen dari produksi total teh nasional (BPS, 2013). Provinsi Jawa Barat merupakan Provinsi penghasil teh terbesar di Indonesia yaitu sebesar 70,75 persen dari total produksi teh nasional (BPS, 2013).

Salah satu produsen teh terbesar di Jawa Barat adalah PT. Perkebunan Nusantara VIII (PTPN VIII). PT. Perkebunan Nusantara VIII merupakan salah satu perkebunan besar negara yang bergerak dalam bidang Agribisnis yang memproduksi teh hitam orthodoks dan CTC. PT. Perkebunan Nusantara VIII
Rancabali Afdeling Rancabali III adalah salah satu dari 44 unit kebun dari PTPN VIII yang telah cukup lama berkecimpung dalam produksi dan pengolahan teh hitam orthodoks dan CTC dengan kualitas teh berstandar nasional dan internasional dan sudah berorientasi ekspor. Jumlah ekspor teh hitam orthodoks di PTPN VIII Rancabali Afdeling Rancabali III mencapai 85 persen dari total produksi keseluruhan.

Sebagai komoditas ekspor perkebunan maka komoditas teh hitam orthodoks harus mempunyai daya saing yang dapat bertahan di pasar internasional dan domestik. Daya saing ini tercermin dari keunggulan komparatif dan kompetitif. PTPN VIII Afdeling Rancabali III mengalami beberapa kendala-kendala dalam pengusahaannya yaitu adanya penurunan luas areal perkebunan teh yang dikarenakan konversi lahan ke tanaman buah dan kayu. Hal ini akan berdampak pula pada produksi teh yang dihasilkan. Selain itu, terjadi kenaikan harga terhadap input seperti pupuk anorganik dan obat-obatan (insektisida, herbisida, fungisida) di PTPN VIII Afdeling Rancabali III. Kendala-kendala yang terjadi di PTPN VIII Afdeling Rancabali III akan mempengaruhi input dan output, dan pada akhirnya akan mempengaruhi daya saing baik keunggulan komparatif maupun kompetitif.

Komoditas teh adalah komoditas perkebunan Indonesia yang berorientasi ekspor, perdagangannya tidak terlepas dari kebijakan pemerintah seperti tarif ekspor nol persen untuk komoditas primer perkebunan, adanya Peraturan 
Menteri Keuangan No.241/PMK.011/ 2010 yang menaikkan pajak impor 5 persen atas produk bahan baku pertanian seperti, pupuk dan obat-obatan dan Peraturan Pemerintah nomor 7 tahun 2007 mengenai Pajak Pertambahan Nilai (PPN) sebesar 10 persen atas input-input produksi seperti peralatan, pupuk dan obat-obatan, serta kebijakan pengenaan Pajak Pertambahan Nilai (PPN) sebesar 10 persen terhadap BBM. Kebijakan pemerintah tersebut erat kaitannya dengan output dan input pengusahaan komoditas teh yang dapat mempengaruhi daya saing. Oleh karena itu diperlukan penelitian mengenai analisis mengenai daya saing dan dampak kebijakan pemerintah terhadap komoditas teh di PT. Perkebunan Nusantara VIII Afdeling Rancabali III. Dengan demikian tujuan penelitian ini adalah:

1. Menganalisis daya saing teh hitam orthodoks di PTPN VIII Afdeling Rancabali III.

2. Menganalisis dampak kebijakan pemerintah terhadap daya saing teh hitam orthodoks di PTPN VIII Afdeling Rancabali III.

3. Menganalisis pengaruh perubahan peningkatan harga jual output, harga pupuk anorganik serta penurunan produksi terhadap daya saing teh hitam orthodoks di PTPN VIII Afdeling Rancabali III.

\section{METODE PENELITIAN}

\section{Lokasi dan Waktu Penelitian}

Pemilihan lokasi penelitian

dilakukan secara purposive (sengaja) yaitu di PT. Perkebunan Nusantara VIII
Rancabali Afdeling Rancabali III dengan pertimbangan bahwa produksi teh terbesar di Indonesia berasal dari perkebunan milik negara, dan PTPN VIII Rancabali ini merupakan salah satu unit perkebunan besar negara yang telah cukup lama berkecimpung dalam produksi dan pengolahan teh hitam orthodoks dan CTC dengan kualitas teh yang baik dan sudah berorientasi ekspor. Selain itu, PTPN VIII Kebun Rancabali merupakan kebun ketiga terbesar yang dimiliki oleh PTPN VIII dan sudah menerapkan ISO 9001:2000.

PT. Perkebunan Nusantara VIII Kebun Rancabali merupakan perkebunan teh yang memiliki luas lahan perkebunan terbesar dari seluruh unit kebun PT. Perkebunan Nusantara VIII. Afdeling Rancabali III merupakan Afdeling dengan produktivitas terbesar dari seluruh Afdeling yang ada di PTPN VIII Rancabali (PTPN VIII Rancabali, 2013). Pengumpulan data terkait dengan penelitian dilakukan pada bulan Juli sampai dengan Agustus 2013.

\section{Jenis dan Sumber Data}

Penelitian ini menggunakan data primer dan data sekunder. Data primer diperoleh melalui observasi dan wawancara dengan tujuh narasumber yaitu Administratur PTPN Rancabali, Kepala bagian tanaman, Kepala bagian pengolahan, Kepala Afdeling Rancabali III, JTU Tanaman, mandor dan pakar teh. Data sekunder diperoleh dari instansi atau lembaga yang terkait dengan penelitian antara lain Dinas Pertanian, Direktorat Jenderal Perkebunan, Badan Pusat Statistik, Kantor Pemasaran 
Bersama PT. Perkebunan Nusantara. PT. Perkebunan Nusantara VIII, Dewan Teh Indonesia, International Tea Committee, United Nations Commodity Trade Statistics Database (COMTRADE), buku-buku literatur, media cetak, dan media elektronik.

\section{Metode Analisis Data}

Metode analisis data yang digunakan dalam penelitian ini adalah metode kualitatif dan metode kuantitatif. Metode kualitatif digunakan untuk mendeskripsikan keragaan usahatani teh hitam orthodoks, sedangkan metode kuantitatif yang digunakan untuk menganalisis daya saing teh hitam orthodoks dan dampak kebijakan pemerintah yaitu analisis Policy Analysis Matrix (PAM) dan analisis sensitivitas. hal ini serupa juga dengan penelitian-penelitian sebelumnya yang sama-sama menggunakan alat analisis PAM (Elbadawi et.al, 2012; Feryanto, 2010; Neptune dan Andrew, 2006; Waqar et.al, 2007).

Adapun analisis PAM yang digunakan dalam penelitian ini merupakan analisis pada tanaman tahunan yang menggunakan Net Present Value NPV) dimana ada proses diskonto (Pranoto, 2011; Rodgers; 2009). Sedangkan penelitian menggunakan analisis sensitivitas juga sebelumya pernah digunakan (Adeg-bite et.all, 2014; Emam, 2011; Ogbe et.al; 2011). Matrix PAM dan indikator dampak kebijakan dapat dilihat pada Tabel 1.

\begin{tabular}{|c|c|c|c|c|}
\hline \multirow{2}{*}{$\begin{array}{c}\text { Ketera- } \\
\text { ngan }\end{array}$} & \multirow{2}{*}{$\begin{array}{c}\text { Peneri- } \\
\text { maan }\end{array}$} & \multicolumn{2}{|c|}{ Biaya } & \multirow{2}{*}{$\begin{array}{l}\text { Keun- } \\
\text { tungan }\end{array}$} \\
\hline & & $\begin{array}{c}\text { Input } \\
\text { Tradable }\end{array}$ & $\begin{array}{l}\text { Input non } \\
\text { Tradable }\end{array}$ & \\
\hline $\begin{array}{l}\text { Harga } \\
\text { Privat }\end{array}$ & A & B & $\mathrm{C}$ & $\mathrm{D}$ \\
\hline $\begin{array}{l}\text { Harga } \\
\text { Sosial } \\
\text { Dampak }\end{array}$ & $\mathrm{E}$ & $\mathrm{F}$ & G & $\mathrm{H}$ \\
\hline $\begin{array}{l}\text { Kebija- } \\
\text { Kan }\end{array}$ & I & $\mathrm{J}$ & $\mathrm{K}$ & $\mathrm{L}$ \\
\hline
\end{tabular}

Sumber: Pearson et.al, 2005

Keterangan :

1. Keuntungan Privat $(\mathrm{D})=\mathrm{A}-(\mathrm{B}+\mathrm{C})$

2. Keuntungan Sosial $(\mathrm{H})=\mathrm{E}-(\mathrm{F}+\mathrm{G})$

3. Transfer Output $(\mathrm{I})=\mathrm{A}-\mathrm{E}$

4. Transfer Input Tradable $(\mathrm{J})=\mathrm{B}-\mathrm{F}$

5. Transfer Input Non Tradable $(\mathrm{K})=\mathrm{C}-\mathrm{G}$

6. Transfer Bersih $(\mathrm{L})=\mathrm{I}-(\mathrm{K}+\mathrm{J})$

7. Rasio Biaya Privat $(\mathrm{PCR})=\mathrm{C} /(\mathrm{A}-\mathrm{B})$

8. Rasio Biaya Sumberdaya Domestik $(D R C)=G /(E-F)$

9. Koefisien Proteksi Output Nominal $(\mathrm{NPCO})=\mathrm{A} / \mathrm{E}$

10. Koefisien Proteksi Input Nominal $(\mathrm{NPCI})=\mathrm{B} / \mathrm{F}$

11. Koefisien Keuntungan $(\mathrm{PC})=\mathrm{D} / \mathrm{H}$

Selanjutnya indikator-indikator pada matrix kebijakan dapat dilihat pada Lampiran 1. Pada penelitian ini memiliki keterbatasan dalam penggunaan alat analisis PAM. Alat analisis PAM merupakan alat analisis untuk menganalisis kebijakan Pemerintah di tingkat usahatani untuk komoditas, namun keterbatasan pada penelitian ini yaitu hanya dilakukan pada kasus di satu perusahaan saja yaitu PTPN VIII Rancabali Afdeling Rancabali III, akan lebih baik jika seluruh perusahaan di PTPN ikut dianalisis juga.

\section{Analisis Sensitivitas}

Dalam penelitian ini, analisis sensitivitas yang digunakan menggunakan metode switching value. Skenarioskenario untuk analisis sensitivitas adalah (1) jika harga jual teh hitam 
orthodoks turun sampai usahatani teh hitam orthodoks tidak memiliki daya saing, (2) jika harga pupuk anorganik naik sampai usahatani teh hitam orthodoks tidak memiliki daya saing, (3) jika jumlah produksi turun sampai usahatani teh hitam orthodoks tidak memiliki daya saing.

\section{HASIL DAN PEMBAHASAN} Kondisi Sistem Agribisnis di Indonesia Perkebunan teh di Indonesia diusahakan oleh tiga pihak yaitu perkebunan rakyat, perkebunan milik negara dan perkebunan milik swasta. Perkebunan teh di Indonesia sudah berkembang pesat, sektor ekspor teh Indonesia mendapat perhatian penting dalam skala internasional mengingat tidak semua negara mampu memproduksi teh dikarenakan faktor iklim. Industri dan perkebunan teh menyerap sekitar 320.000 tenaga kerja dan menghidupi sekitar 1,3 juta jiwa. Produksi teh juga masih berpotensi terus bertambah seiring perkembangan produk turunan teh yang semakin pesat, baik berupa minuman siap saji, serta berbagai produk lain yang berpotensi pada kesegaran, kesehatan, kecantikan dan kebugaran bagi yang menkonsumsinya. Inilah yang menjadi faktor penting mengapa eksistensi agribisnis teh di Indonesia perlu terus dikembangkan oleh seluruh stakeholder teh sehingga ke depan dapat menjadi komoditas unggulan.

Hingga kini perkembangan kinerja agribisnis teh Indonesia cukup memprihatinkan yang ditandai terjadinya penurunan areal, kenaikan biaya pro- duksi, mutu teh rakyat yang masih rendah dan belum memenuhi SNI, mesin dan peralatan dalam keadaan tidak mendukung. Permasalahan yang dihadapi pertahanan nasional mencakup seluruh subsistem, mulai dari usaha tani/on farm sampai dengan pemasaran.

Oleh karena itu, berbagai upaya perbaikan harus dilakukan disetiap subsistem secara komprehensif dan terintegrasi. Perkebunan teh memiliki dampak positif bagi lingkungan sekitar. Perkebunan dapat mendukung konservasi tanah dan air (lahan tertutup tajuk tanaman teh hampir 95 persen) dengan baik bila dikelola secara benar. Dari aspek hidrologis berfungsi sebagai daerah resapan air, sumber air bagi kehidupan sekitarnya. Dapat menekan polusi udara, dapat menyerap $\mathrm{CO} 2$ sebanyak 2,5 ton setara karbon per hektar tanaman per tahun.

Akan tetapi perkebunan teh nasional dihadapkan pada berbagai tantangan baik di tingkat nasional maupun internasional. Dengan kondisi persaingan yang ketat, keunggulan daya saing (competitive advantage) dan nilai tambah (added value) komoditas teh menjadi faktor yang menentukan dalam memenangi persaingan. Dalam susbsistem agribisnis, subsitem hulu sangat rentan kaitannya dalam menentukan kualitas budidaya teh. Dengan kualitas bibit yang baik, sarana produksi pertanian yang qualified serta pupuk yang berkualitas dapat menghasilkan bibit yang memiliki daya saing untuk dibudidayakan. 


\section{Analisis Daya Saing dan Dampak Kebijakan Pemerintah}

Pada bab ini akan dibahas mengenai hasil perhitungan pada Policy Analysis Matrix (PAM) yang merefleksikan daya saing komoditas teh dan dampak kebijakan Pemerintah terhadap komoditas teh di PT. Perkebunan Nusantara VIII Afdeling Rancabali III. Analisis ini dilakukan secara multiperiode yaitu selama 25 tahun. Tingkat suku bunga privat dan sosial yang digunakan adalah sebesar 6 persen (asumsi menggunakan suku bunga bank milik Pemerintah 2012). Proses diskonto diperlukan dalam penelitian ini untuk menentukan Net Present Value (NPV) dari masing-masing bagian tersebut.

Matrix PAM terdiri dari tiga baris (harga privat, harga sosial, dan efek divergensi) dan empat kolom yang secara berurutan terdiri dari kolom penerimaan, kolom biaya yang terdiri dari input tradable dan input non tradable, dan kolom keuntungan yang merupakan selisih dari penerimaan dengan biayabiaya. Berdasarkan hasil analisis keuntungan, maka didapatkan hasil yaitu nilai keuntungan privat yang diperoleh sebesar Rp. 469.803.837 per hektar, dan keuntungan sosial sebesar Rp. 316.555.288 per hektar. Maka, dapat disimpulkan bahwa pengusahaan teh hitam orthodoks di PTPN VIII Afdeling Rancabali III menguntungkan dan layak secara finansial maupun ekonomi. Hal ini juga menyebabkan divergensi yang dihasilkan bernilai positif yaitu sebesar Rp. 153.248.548 per hektar. Secara lengkap hasil perhitungan analisis PAM dapat dilihat pada Lampiran 2.
Analisis daya saing teh hitam orthodoks di PTPN VIII Afdeling Rancabali III dapat dilihat dari keunggulan komparatif dan keunggulan kompetitif. Keunggulan komparatif dapat dilihat dari nilai Rasio Sumberdaya Domestik (Domestic Resource Cost) DRC) dan keuntungan sosial (Social Profit/SP). Adapun nilai DRC adalah 0,74 . Artinya, jika teh hitam orthodoks diproduksi di dalam negeri maka hanya membutuhkan biaya sebesar 0,74 satu satuan, sehingga terjadi penghematan biaya sebesar 0,74 satu satuan. Hal ini berarti, jika memproduksi teh hitam orthodoks di dalam negeri akan menjadi lebih murah dibandingkan jika mengimpor dari negara lain sehingga teh hitam orthodoks berdaya saing karena memiliki keunggulan komparatif. Hal ini mengindikasikan bahwa untuk memproduksi teh hitam orthodoks di PTPN VIII Afdeling Rancabali III hanya membu-tuhkan biaya sumberdaya domestik sebesar 74 persen terhadap biaya impor yang dibutuhkan. Nilai keuntungan sosial/ekonomi yang dihasilkan sebesar Rp.316.555.288 per hektar. Jadi, dapat dikatakan bahwa usahatani teh hitam orthodoks efisien secara ekonomi/sosial dan memiliki keunggulan komparatif karena meiliki nilai $\mathrm{DRC}<1$. Hal ini menunjukkan pula meskipun tanpa kebijakan atau intervensi pemerintah, usahatani teh hitam orthodoks masih layak dan menguntungkan jika diproduksi.

Keunggulan kompetitif teh hitam orthodoks Afdeling Rancabali III ditunjukkan oleh nilai Rasio Biaya Privat (Privat Cost Ratio/PCR) dan keuntungan privat (Privat Profit/PP). Adapun nilai 
PCR di PTPN VIII Afdeling Rancabali III adalah sebesar 0,67. Hal ini menunjukkan bahwa untuk mendapatkan nilai tambah output sebesar satu satuan dibutuhkan tambahan biaya faktor domestik kurang dari satu satuan yaitu sebesar 0,67. Berdasarkan nilai PCR tersebut, maka komoditas teh hitam orthodoks di PTPN VIII Afdeling Rancabali III dapat dikatakan memiliki keunggulan kompetitif karena memiliki nilai $\mathrm{PCR}<1$, Hal ini menunjukkan bahwa untuk mendapatkan nilai tambah output sebesar satu satuan dibutuhkan tambahan biaya faktor domestik kurang dari satu satuan yaitu sebesar 0,67. Nilai PCR sebesar 0,67 menunjukkan bahwa untuk mendapatkan nilai tambah output teh hitam orthodoks di PTPN VIII Afdeling Rancabali III sebesar satu satuan pada harga privat, maka diperlukan tambahan biaya faktor domestik kurang dari satu satuan yaitu sebesar 0,67. Adapun nilai keuntungan privat yang dihasilkan adalah bernilai positif sebesar Rp. 469.803.837 per hektar. Dengan demikian, usahatani komoditas teh hitam orthodoks Afdeling Rancabali III menguntungkan secara finansial dan dapat bersaing pada tingkat harga privat.

Keunggulan kompetitif akan meningkat jika biaya faktor domestik dapat diminimumkan dan atau memaksimalkan nilai tambah output (Pranoto, 2011). Menurut Pranoto (2011), Peningkatan nilai tambah output dapat ditingkatkan dengan penggunaan teknologi yang dapat menurunkan biaya per unit output.
Perbandingan selanjutnya yang dapat disimpulkan adalah nilai keuntungan privat yang lebih besar dibandingkan keuntungan sosialnya. Hal ini berarti usahatani teh hitam orthodoks di PTPN VIII Afdeling Rancabali III lebih menguntungkan saat adanya intervensi dari pemerintah. Divergensi keuntungan menunjukkan angka positif sebesar Rp. 153.248.548 per hektar. Selanjurtnya dilihat dari nilai PCR yang dihasilkan lebih besar daripada nilai DRC. Hal ini berarti komoditas teh yang dihasilkan PTPN VIII Afdeling Rancabali III didukung oleh kebijakan atau intervensi Pemerintah yang meningkatkan efisiensi dalam berproduksi. Artinya, kebijakan terkait input-output yaitu pajak bea masuk atas input produksi (pupuk anorganik dan obat-obatan) sebesar 5 persen dan PPN 10 persen, dan pengenaan PPN terhadap BBM sebesar 10 persen sudah efektif untuk meningkatkan daya saing dan memberikan keuntungan bagi PTPN VIII Afdeling Rancabali III.

\section{Analisis Dampak Kebijakan Pemerintah}

Pada analisis dampak kebijakan pemerintah ini akan dibahas mengenai kebijakan output, kebijakan input, dan kebijakan input-output. Secara lengkap dibahas pada Lampiran 3.

\section{Kebijakan Output}

Nilai Transfer Output (TO) dari usahatani komoditas teh hitam orthodoks bernilai positif yaitu sebesar Rp. 239.564.941, hal ini berarti konsumen membeli dengan harga yang tinggi dari harga yang seharusnya dibayarkan 
kepada produsen. Artinya harga output teh hitam orthodoks di pasar domestik lebih tinggi dari harga internasionalnya. Hal ini bisa terlihat dari harga output pada struktur harga privat yang lebih tinggi dibandingkan harga sosialnya yaitu Rp. 22.116 per kg (harga privat) dan Rp. 18.816 per $\mathrm{Kg}$ (harga sosial). Perbedaan harga antara privat dan sosial diduga karena adanya pengenaan pajak PPn sebesar 10 persen terhadap BBM. Saat ini belum ada kebijakan Pemerintah yang langsung mengenai output teh hitam orthodoks. Namun ada kebijakan pengenaan PPN terhadap BBM yang tertuang dalam Undang-Undang No 42 Tahun 2009 tentang perubahan ketiga atas Undang-Undang No 8 tahun 1983 tentang Pajak Pertambahan Nilai Barang dan Jasa dan Pajak atas Penjualan barang mewah yang mulai berlaku tanggal 1 April 2010 serta berlakunya Peraturan Pajak Penghasilan Pasal 22 berkenaan dengan pengenaan PPN sebesar 10 persen terhadap BBM. Sedangkan untuk nilai Koefisien Proteksi Output (NPCO) adalah rasio antara penerimaan berdasarkan harga privat dengan penerimaan berdasarkan harga sosial. Penerimaan privat yaitu sebesar Rp. 1.590.857.428 per hektar, sedangkan penerimaan sosial sebesar Rp. 1.351.292.487 per hektar, sehingga didapatkan nilai NPCO sebesar 1,18. Nilai NPCO yang dihasilkan adalah lebih besar dari satu (NPCO $>1)$, Artinya harga output teh hitam orthodoks di pasar domestik lebih tinggi dari harga internasionalnya. Hal ini bisa terlihat dari harga output pada struktur harga privat yang lebih tinggi dibandingkan harga sosialnya yaitu Rp. 22.116 per kg (harga privat) dan Rp. 18.816 per Kg (harga sosial). Perbedaan harga antara privat dan sosial diduga karena adanya pengenaan pajak PPN sebesar 10 persen terhadap BBM. Saat ini belum ada kebijakan Pemerintah yang langsung mengenai output teh hitam orthodoks. Meskipun belum ada kebijakan secara khusus yang memproteksi output teh hitam orthodoks namun, kebijakan pengenaan PPN sebesar 10 persen untul BBM akan menambah biaya untuk transportasi untuk pemasaran output dan pengangkutan output berpengaruh secara tidak langsung terhadap output. Hal ini juga berarti pemerintah memberikan proteksi pada usaha perkebunan di PTPN VIII Afdeling Rancabali III dengan cara menaikkan harga output diatas harga efisiennya. Secara keseluruhan, analisis dampak kebijakan pemerintah terhadap output yaitu pengenaan PPN untuk BBM sebesar 10 persen terhadap output teh hitam orthodoks di PTPN VIII Afdeling Rancabali III mengindikasikan bahwa kebijakan tersebut efektif atau mampu mendorong peningkatan daya saing.

\section{Kebijakan Input}

Nilai Tranfer Input (TI) dalam penelitian ini adalah sebesar Rp. 27.153.923. Hal ini mengindikasikan bahwa dalam usahatani teh hitam orthodoks, harga input tradable yang dikeluarkan pada harga privat lebih tinggi daripada harga input pada harga sosial/ ekonomi sehingga PTPN VIII Afdeling Rancabali III membayar input lebih besar sebesar Rp. 27.153.923 daripada kondisi seharusnya akibat adanya kebijakan pemerintah. Hal ini dikarenakan PTPN 
VIII Afdeling Rancabali III tidak mendapatkan subsidi dari Pemerintah, bahkan PTPN VIII Afdeling Rancabali ini membayar input dengan harga yang jauh lebih mahal. bahkan PTPN VIII Afdeling Rancabali ini membayar input dengan harga yang jauh lebih mahal karena terkena pajak. Kebijakan yang mempengaruhi input antara lain kebijakan bea masuk produk bahan baku impor sebesar 5 persen. Pada tanggal 22 Desember 2010, Pemerintah mengeluarkan Peraturan Menteri Keuangan (PMK) No.241/PMK.011/2010 yang menjadi dasar kebijakan kenaikan bea masuk atas impor barang, berikutnya kebijakan terkait Peraturan Pemerintah nomor 7 tahun 2007 mengenai Pajak Pertambahan Nilai (PPN) sebesar 10 persen atas inputinput produksi seperti peralatan, pupuk dan obat-obatan serta adanya pengenaan PPN sebesar 10 persen terhadap BBM.

Nilai Koefisien Proteksi Input Nominal (NPCI) adalah perbandingan antara biaya input tradable berdasarkan harga privat dengan biaya input tradable berdasarkan harga sosial/ekonomi. Nilai NPCI yang dihasilkan yaitu sebesar 1,17. Hal ini menunjukkan bahwa pemerintah menaikkan harga input tradable di pasar domestik yang dihadapi PTPN VIII Afdeling Rancabali III dibawah harga dunia. Jadi, kebijakan pemerintah terhadap input tidak mendorong peningkatan daya saing teh hitam orthodoks di lokasi penelitian. Nilai NPCI $>1$ menunjukkan adanya proteksi pemerintah terhadap produsen input tradable di pasar domestik. Hal ini terjadi dikarenakan adanya kebijakan pemerintah berupa adanya beamasuk (pajak impor) dan Pajak Pertambahan Nilai input tradable seperti pupuk anorganik dan obat-obat-obatan (Mantau 2009, Saptana et.al 2004).

Selain input tradable, input lain yang digunakan dalam proses produksi adalah input domestik (faktor domestik). Harga atas input tersebut ditentukan oleh mekanisme pasar lokal atau di dalam negeri. Transfer Faktor (TF) merupakan indikator dampak kebijakan pemerintah terhadap input produksi tersebut. TF merupakan selisih antara biaya input domestik yang dihitung pada harga privat dengan biaya input produksi pada harga bayangan (sosial). Nilai Transfer Factor (TF) adalah perbedaan harga sosial dengan harga privat yang diterima PTPN VIII Afdeling Rancabali III untuk pembayaran faktor-faktor produksi domestik. Adapun nilai Transfer Factor (TF) pada peneliitan ini adalah memiliki nilai positif yaitu sebesar Rp. 59.162.469. Hal ini mengindikasikan bahwa harga input domestik/non tradable yang dikeluarkan pada tingkat harga privat lebih tinggi daripada tingkat harga sosial/ ekonomi. Hal ini diduga karena adanya pemberlakuan peraturan menge-nai Upah Minimum Regional untuk tenaga kerja sehingga biaya input untuk faktor domestik di struktur privat lebih tinggi jika dibandingkan dengan di struktur sosial. Disamping itu, nilai tersebut menunjukkan bahwa terdapat implisit pajak pertambahan nilai pada input non tradable (faktor domestik) dari Pemerintah yaitu pengenaan PPN BBM sebesar 10 persen untuk jenis premium.

Secara keseluruhan, kebijakan pemerintah terhadap input produksi yaitu 
pajak bea masuk atas input produksi sebesar 5 persen dan PPN sebesar 10 persen serta pengenaan PPN sebesar 10 dan kebijakan terkait Upah Minimum Regional (UMR) persen belum efektif atau belum mampu mendorong peningkatan daya saing teh hitam orthodoks di PTPN VIII Afdeling Rancabali III.

\section{Kebijakan Input-Output}

Indikator untuk kebijakan inputoutput adalah Transfer Bersih (TB), Koefisien Proteksi Efektif (EPC), Rasio Subsidi Produsen (SRP), dan Koefisien keuntungan (PC). Nilai Transfer Bersih merupakan selisih dari nilai keuntungan privat dengan nilai keuntungan sosial. Nilai Transfer Bersih bernilai positif yaitu sebsar Rp. 153.248.548. Hal ini menunjukkan bahwa adanya penambahan keuntungan untuk PTPN VIII Afdeling Rancabali III yang disebabkan adanya kebijakan pemerintah. Nilai tersebut juga merefleksikan bahwa dampak kebijakan pemerintah terhadap input dan output akan meningkatkan surplus PTPN VIII Afdeling Rancabali III yaitu sebesar Rp. 153.248.548. Oleh karena itu, kebijakan kenaikan bea masuk atas impor barang sebesar 5 persen dan Peraturan Pemerintah nomor 7 tahun 2007 mengenai Pajak Pertambahan Nilai (PPN) sebesar 10 persen atas input-input produksi seperti peralatan, pupuk dan obat-obatan dan adanya pengenaan PPN sebesar 10 persen terhadap BBM efektif bagi usahatani teh hitam orthodoks di PTPN VIII Afdeling Rancabali III.

Nilai EPC menggambarkan sejauh mana kebijakan pemerintah bersifat melindungi produksi domestik secara efektif. Jika nilai EPC kurang dari satu,maka kebijakan tersebut tidak berjalan secara efektif atau menghambat produsen untuk berproduksi. Nilai EPC di lokasi peneltiian adalah sebesar 1,18. Secara umum nilai EPC juga menggambarkan bahwa terdapat kebijakan Pemerintah terhadap harga input dan output yang efektif untuk melindungi PTPN VIII Afdeling Rancabali III. Kebijakan yang berkaitan dengan input dan output yaitu pajak bea masuk atas input produksi sebesar 5 persen serta pengenaan PPN sebesar 10 persen dan kebijakan Pemerintah terhadap pengenaan PPN terhadap BBM sebesar 10 persen dalam melindungi produksi domestik secara efektif.

Indikator dampak kebijakan terhadap input-output selanjutnya adalah SRP atau Rasio Subsidi bagi Produsen. Berdasarkan Lampiran 3, menunjukkan bahwa nilai $\mathrm{SRP}>0$, yaitu sebesar 0,11 yang artinya bahwa kebijakan Pemerintah yang berlaku menyebabkan PTPN VIII Afdeling Rancabali III mengeluarkan biaya lebih rendah sekitar 11 persen dari biaya opportunity cost untuk berproduksi. Oleh karena itu, kebijakan Pemerintah yang berkaitan dengan input dan output yaitu pajak bea masuk atas input produksi sebesar 5 persen dan PPN sebesar 10 persen serta pengenaan PPN sebesar 10 persen terhadap BBM ini menguntungkan bagi peningkatan daya saing komoditas teh hitam orthodoks di PT. Perkebunan Nusantara VIII Afdeling Rancabali III.

Pada Koefisien Keuntungan (PC) mampu menjelaskan dampak insentif 
dari seluruh kebijakan output, kebijakan input asing (tradable) dan input domestik (net policy transfer). Koefisien Keuntungan adalah perbandingan antara keuntungan bersih privat dengan keuntungan bersih sosial. Berdasarkan nilai PC pada Lampiran 3 adalah 1,48. Hasil penelitian menunkukkan bahwa nilai PC $>$ 1, dimana nilai tersebut menunjukkan bahwa dengan kebijakan pemerintah yang ada mengakibatkan keuntungan yang diterima PTPN VIII Afdeling Rancabali III lebih besar jika dibandingkan tanpa adanya kebijakan. Nilai tersebut juga menunjukkan bahwa dengan kebijakan Pemerintah yang berlaku seperti pajak bea masuk atas input produksi sebesar 5 persen dan PPN sebesar 10 persen serta pengenaan PPN sebesar 10 persen terhadap BBM mengakibatkan keuntungan yang diterima PTPN VIII Afdeling Rancabali III lebih besar jika dibandingkan tanpa adanya kebijakan. Hal ini mengindikasikan bahwa kebijakan Pemerintah yang ada dapat meningkatkan produksi teh hitam orthodoks di lokasi penelitian.

Secara keseluruhan dapat disimpulkan bahwa kebijakan pemerintah terhadap input-output yang ada selama ini yaitu pajak bea masuk 5 persen dan PPN 10 persen atas input produksi seperti pupuk anorganik dan obat-obatan serta pengenaan PPN terhadap BBM sebesar 10 persen melindungi PTPN VIII Afdeling Rancabali III secara efektif.

\section{Analisis Sensitivitas Usahatani Teh Hitam Orthodoks}

Analisis sensitivitas dalam penelitian ini menggunakan metode switching value. Tujuan analisis sensitivitas pada penelitian ini untuk mengetahui sampai berapa persen masing-masing variabel dan kombinasi variabel tersebut diubah sehingga usahatani teh hitam orthodoks memperoleh keuntungan yang negatif atau tidak memiliki daya saing (PCR $>1$ dan DRCR>1).

Pada penelitian ini digunakan tiga skenario analisis sensitivitas. Skenarioskenario tersebut adalah (1) jika harga jual teh hitam orthodoks turun sampai usahatani teh hitam orthodoks tidak memiliki daya saing, (2) jika harga pupuk anorganik naik sampai usahatani teh hitam orthodoks tidak memiliki daya saing, (3) jika jumlah produksi turun sampai usahatani teh hitam orthodoks tidak memiliki daya saing.

Berdasarkan hasil analisis sensitivitas maka didapatkan hasil bahwa pada skenario kesatu (jika harga jual teh turun 30 persen) sehingga keuntungan privat usahatani yang dihasilkan yaitu sebesar -Rp 11.836.223 dan keuntungan sosial yang diperoleh sebesar -Rp 70.254.415. Skenario kedua (jika harga pupuk anorganik naik 100 persen) maka keuntungan privat usahatani teh hitam orthodoks yang dihasilkan yaitu sebesar -Rp 16.553.204 dan keuntungan sosial yang diperoleh yaitu -Rp 93.880.297. Selanjutnya pada skenario ketiga (jika jumlah produksi turun sebesar 37 persen), maka keuntungan privat usahatani teh hitam orthodoks yang dihasilkan adalah sebesar -Rp 17.945.267 dan keuntungan sosial usahatani teh hitam orthodoks yang diperoleh adalah sebesar $-\operatorname{Rp} 78.279 .621$. 
Tabel 2. Keuntungan Usahatani Teh Hitam Orthodoks Berdasarkan Analisis Sensitivitas

\begin{tabular}{clcccc}
\hline \multirow{2}{*}{ No } & \multicolumn{1}{c}{ Skenario } & \multicolumn{2}{c}{$\begin{array}{c}\text { Keuntungan sebelum } \\
\text { Analisis Sensitivitas (Rp) }\end{array}$} & \multicolumn{2}{c}{$\begin{array}{c}\text { Keuntungan setelah } \\
\text { Analisis Sensitivitas (Rp) }\end{array}$} \\
\cline { 2 - 6 } & \multicolumn{1}{c}{ Privat } & \multicolumn{1}{c}{ Sosial } & Privat & Sosial \\
\hline 1 & $\begin{array}{l}\text { Harga jual teh turun } \\
30 \%\end{array}$ & 469.803 .837 & 316.555 .288 & -11.836 .223 & -70.254 .415 \\
\multirow{2}{*}{2} & $\begin{array}{l}\text { Harga pupuk } \\
\text { anorganik naik 100\% }\end{array}$ & 469.803 .837 & 316.555 .288 & -16.553 .204 & -93.880 .297 \\
\multirow{2}{*}{3} & $\begin{array}{l}\text { Jumlah produksi } \\
\text { turun 37\% }\end{array}$ & 469.803 .837 & 316.555 .288 & -17.945 .267 & -78.279 .621 \\
\hline
\end{tabular}

Selanjutnya, tujuan dari analisis sensitivitas ini juga ingin melihat sejauh mana perubahan-perubahan pada variabel-variabel sampai usahatani teh hitam orthodoks tidak memiliki daya saing. Indikator dari daya saing itu sendiri adalah untuk keunggulan kompetitif yaitu nilai Private Cost Ratio (PCR) dan keuntungan privat. Sedangkan indikator-indikator untuk keunggulan komparatif yaitu nilai Domestic Cost Ratio (DRC) dan keuntungan sosial. Hasil analisis sensitivitas untuk daya saing teh hitam orthodoks dapat dilihat pada Tabel 3.

Berdasarkan Tabel 3, maka dapat diketahui bahwa ketika tejadi skenario kesatu dimana ketika terjadi harga jual teh menurun 30 persen maka nilai Private
Cost Ratio (PCR) yang dihasilkan yaitu 1,01, sedangkan nilai Domestic Cost Ratio (DRC) yang diperoleh yaitu 1,09. Selanjutnya ketika terjadi skenario kedua yaitu jika harga pupuk anorganik naik hingga 100 persen maka daya saing yang dihasilkan yaitu nilai Private Cost Ratio (PCR) sebesar 1,01 dan nilai Domestic Cost Ratio (DRC) sebesar 1,09. Pada skenario ketiga yaitu jika jumlah produksi turun sebesar 37 persen maka daya saing yang tercermin dari nilai Private Cost Ratio (PCR) dan Domestic Cost Ratio (DRC) yaitu sebesar 1,02 dan 1,11. Berdasarkan hasil analisis sensitivitas pada Tabel 3 menunjukkan bahwa harga jual, harga pupuk anorganik dan jumlah produksi sensitif mempengaruhi daya saing usahatani teh hitam

Tabel 3. Daya Saing Usahatani Teh Hitam Orthodoks Berdasarkan Analisis Sensitivitas

\begin{tabular}{llcc}
\hline No & \multicolumn{1}{c}{ Skenario } & \multicolumn{2}{c}{ Indikator Daya Saing } \\
\cline { 3 - 4 } & & PCR & DRCR \\
\hline \multirow{2}{*}{1} & Kondisi Normal & 0,67 & 0,74 \\
2 & Harga jual teh menurun 30\% & 1,01 & 1,09 \\
3 & Jarga pupuk anorganik naik 100\% & 1,01 & 1,09 \\
\hline
\end{tabular}


orthodoks di PTPN VIII Afdeling Rancabali III.

Berdasarkan hasil analisis sensitivitas maka didapatkan hasil bahwa pada skenario kesatu (jika harga jual teh turun 30 persen) sehingga keuntungan privat usahatani yang dihasilkan yaitu sebesar Rp 11.836.223 dan keuntungan sosial yang diperoleh sebesar -Rp 70.254.415. Skenario kedua (jika harga pupuk anorganik naik 100 persen) maka keuntungan privat usahatani teh hitam orthodoks yang dihasilkan yaitu sebesar Rp 16.553.204 dan keuntungan sosial yang diperoleh yaitu sebesar -Rp 93.880.297. Selanjutnya pada skenario ketiga (jika jumlah produksi turun sebesar 37 persen) maka keuntungan privat usahatani teh hitam orthodoks yang dihasilkan yaitu sebesar -Rp 17.945.267 dan keuntungan sosial usahatani teh hitam orthodoks yang diperoleh adalah sebesar -Rp 78.279.621.

Selanjutnya, tujuan dari analisis sensitivitas ini juga ingin melihat sejauh mana perubahan-perubahan pada variabel-variabel sampai usahatani teh hitam orthodoks tidak memiliki daya saing. Indikator dari daya saing itu sendiri adalah untuk keunggulan kompetitif yaitu nilai Private Cost Ratio (PCR) dan keuntungan privat. Sedangkan indikatorindikator untuk keunggulan komparatif yaitu nilai Domestic Cost Ratio (DRC) dan keuntungan sosial. Hasil analisis sensitivitas untuk daya saing teh hitam orthodoks di PTPN VIII Afdeling Rancabali III dapat dilihat pada Tabel 3.

Berdasarkan Tabel 3, maka dapat diketahui bahwa ketika tejadi skenario kesatu dimana ketika terjadi harga jual teh menurun 30 persen maka nilai Private Cost Ratio (PCR) yang dihasilkan yaitu 1,01, sedangkan nilai Domestic Cost Ratio (DRC) yang diperoleh yaitu 1,09. Selanjutnya ketika terjadi skenario kedua yaitu jika harga pupuk anorganik naik hingga 100 persen maka daya saing yang dihasilkan yaitu nilai Private Cost Ratio (PCR) sebesar 1,01 dan nilai Domestic Cost Ratio (DRC) sebesar 1,09. Pada skenario ketiga yaitu jika jumlah produksi turun sebesar 37 persen maka daya saing yang tercermin dari nilai Private Cost Ratio (PCR) dan Domestic Cost Ratio (DRC) yaitu sebesar 1,02 dan 1,11. Berdasarkan hasil analisis sensitivitas pada Tabel 3 menunjukkan bahwa harga jual, harga pupuk anorganik dan jumlah produksi sensitif mempengaruhi daya saing usahatani teh hitam orthodoks di PTPN VIII Afdeling Rancabali III.

\section{Simpulan}

\section{SIMPULAN DAN SARAN}

Adapun kesimpulan yang dapat diambil dari penelitian ini adalah :

1. Komoditas teh hitam orthodoks di PTPN VIII Afdeling Rancabali III memiliki daya saing baik keunggulan kompetitif dan kom-paratif karena efisien secara produksi, nilai PCR dan DRC yang diperoleh kurang dari satu serta menguntungkan secara finansial dan ekonomi.

2. Secara keseluruhan kebijakan terhadap input-output di PTPN VIII Afdeling Rancabali III efektif serta mendukung peningkatan daya saing teh hitam orthodoks di PTPN VIII Afdeling Rancabali III. Kebijakan 
Pemerintah tersebut berupa pajak bea masuk dan PPN atas input produksi (pupuk anorganik dan obat-obatan) serta pengenaan PPN terhadap BBM.

3. Berdasarkan hasil analisis sensitivitas menunjukkan bahwa harga jual teh hitam orthodoks, harga pupuk anorganik dan jumlah produksi teh hitam orthodoks sensitif mempengaruhi daya saing usahatani teh hitam orthodoks di PTPN VIII Afdeling Rancabali III.

\section{Saran}

Berdasarkan kesimpulan dan hasil analisis yang diperoleh maka dapat dirumuskan beberapa saran rekomendasi kebijakan:

1. Bagi perusahaan, perubahan harga jual output, harga pupuk anorganik dan jumlah produksi berpengaruh terhadap daya saing komoditas teh hitam orthodoks. Oleh karena itu, Perusahaan sebaiknya mempunyai alternatif-alternatif strategi untuk mempertahankan dan meningkatkan daya saing teh hitam orthodoks.

2. Bagi perusahaan, upaya-upaya lain untuk dapat meningkatkan daya saing adalah peningkatan kualitas teh yaitu dengan diversifikasi produk olahan teh agar dapat bisa lebih bersaing dengan negara pesaing lainnya.

3. Bagi akademisi, disarankan untuk penelitian lanjutan dapat dilakukan analisis daya saing dan dampak kebijakan Pemerintah berdasarkan grade teh (teh hitam dan teh hijau) dengan responden seluruh perusahaan yang tergabung dalam PT. Perkebunan Nusantara.

\section{DAFTAR PUSTAKA}

Adegbite Olayinka, Oni Omobowale, Adeoye Iyabo. 2014. Competitiveness of Pineapple Production in Osun State Nigeria. Journal of Economics and Sustainable Development [Internet]. [diunduh 2014 Mar 27];5(2):205-214. Tersedia pada: http://www.iiste.org/ Journals/index.php/JEDS/ article/view10712.

[BPS] Badan Pusat Statistik. 2012. Jawa Barat Dalam Angka Tahun 2011. Jakarta (ID): Badan Pusat Statistik DKI Jakarta.

[BPS] Badan Pusat Statistik. 2013. Statistik Teh Indonesia. Jakarta (ID): Badan Pusat Statistik DKI Jakarta. Direktorat Jenderal Perkebunan. Departemen Pertanian.

Elbadawi, Elsedig; Arshad, Fatimah Mohamed; Mohammed, Zainalabdin; Ismail, Mohd Mansor. 2012. Assessing the competitiveness of sheep production in selected states in Sudan. Journal of Agricultural Science [Internet]. [diunduh 2014 Jan14];5(1):75-83. Tersedia pada: http://www.ccsenet.org/ journal.

Emam, Abda Abdalla. 2011. The Competitiveness of sugar cane production: a study of kenana sugar company Sudan. Journal of Agricultural Science [Internet]. [diunduh 2013 Des 10];3(3):202-210. Tersedia pada: http://sustech.edu/ staff_publications /20110921064221790.pdf

Feryanto. 2010. Analisis daya saing dan dampak kebijakan pemerintah terhadap komoditas susu sapi lokal 
di Jawa Barat [tesis]. Bogor (ID): Institut Pertanian Bogor.

Mantau, Z. 2009. Analisis keunggulan komparatif dan kompetitif usahatani jagung dan padi di kabupaten Bilalang Mongondow Provinsi Sulawesi Utara [tesis]. Bogor (ID): Institut Pertanian Bogor.

Monke, E.A and Scott, Pearson. 1989. The Policy Analisys Matrix forAgricultural Development. Itacha and London.Cornell University Press.

Neptune, Lueandra; Jacque, Andrew. 2006. Competitiveness Of Cocoa Production Systems In Trinidad And Tobago. Proceeding of the 26th West Indies Agricultural Economics Conference (Caribbean AgroEconomics Society) [Internet]. [2006 Juli]. Puerto Rico:CAES. hlmn 50-58; [diunduh 2013 Des. 30.Tersedia pada: http: ageconsearch.umn.edu.

Ogbe Agatha Osivweneta, Okuruwa Victor O, Saka Olaide J. 2011. Competitiveness of nigerian rice and maize production ecologies: a policy analysis approach. Journal of Tropical and Subtropical Agroecp system [Internet]. [diunduh 2013 Desember. 30];14(2011):493-500. Tersedia pada http://www.veterinaria.uady.mx/ojs /index.

php/TSA/article/view/929/580.

Pearson S, Carl G, Bahri S. 2005. Aplikasi Policy Analysis Matrix Pada Pertanian Indonesia. Jakarta (ID): Yayasan Obor.
Pranoto. S, Yudi. 2011. Dampak kebijakan pemerintah terhadap keuntungan dan daya saing lada putih (Muntok White Paper) di Provinsi Bangka Belitung [tesis]. Bogor (ID): Institut Pertanian Bogor.

Rodger, A. 2008. Economic analysis of smallholder rubber agroforestry system efficiency in Jambi [tesis]. Bogor (ID): Institut Pertanian Bogor.

Saptana, Friyatno S, Bastuti TP. 2004. Analisis dayasaing komoditi tembakau rakyat di Klaten Jawa Tengah. Journal of Socio-Economic Of Agriculture And Agribusiness [Internet]. [diunduh 2013 Des. 30];4(2):1-26.Tersedia pada : http://ojs.unud.ac.id/index.php/soca /article/view/4048/3037.

Waqar, Akhtar; Sharif, Muhammad; Akmal, Nadeem. 2007. Analysis of economic efficiency and competitiveness of the rice production systems of Pakistan's Punjab.The Lahore journal of economics [Internet]. [diunduh 2013 Mar 10]; 12(1):141-153.Tersedia pada:http://ideas.repec.org/a/lje/jour nl/v12y2007ilp141-153.html. 


\section{Lampiran 1. Indikator-Indikator Matriks Kebijakan}

\begin{tabular}{lrr}
\hline \multicolumn{1}{c}{ Uraian } & \multicolumn{1}{c}{ Rumus } & \multicolumn{1}{c}{ Indikator } \\
\hline Privat Profits (Keuntungan Privat) & $\mathrm{D}=\mathrm{A}-\mathrm{B}-\mathrm{C}$ & $\mathrm{D}>0$ \\
Sosial Profits (Keuntungan Sosial) & $\mathrm{H}=\mathrm{E}-\mathrm{F}-\mathrm{G}$ & $\mathrm{H}>0$ \\
Transfer Ouput & $\mathrm{I}=\mathrm{A}-\mathrm{E}$ & $\mathrm{I}>0$ \\
Transfer Input & $\mathrm{J}=\mathrm{B}-\mathrm{F}$ & $\mathrm{J}>0$ \\
Transfer Faktor & $\mathrm{K}=\mathrm{C}-\mathrm{G}$ & $\mathrm{K}>0$ \\
Transfer Bersih & $\mathrm{L}=\mathrm{D}-\mathrm{H} ; \mathrm{L}=\mathrm{I}-\mathrm{J}-\mathrm{K}$ & $\mathrm{L}>0$ \\
Rasio Biaya Privat & $\mathrm{PCR}=\mathrm{C} /(\mathrm{A}-\mathrm{B})$ & $\mathrm{PCR}<1$ \\
Rasio Biaya Sumber Daya Domestik & $\mathrm{DRCR}=\mathrm{G} /(\mathrm{E}-\mathrm{F})$ & $\mathrm{DRCR}<1$ \\
Koefisien Proteksi Output Nominal & $\mathrm{NPCO}=\mathrm{A} / \mathrm{E}$ & $\mathrm{NPCO}>1$ \\
Koefisien Proteksi Input Nominal & $\mathrm{NPCI}=\mathrm{B} / \mathrm{F}$ & $\mathrm{NPCI}<1$ \\
Koefisien Proteksi Efektif & $\mathrm{EPC}=(\mathrm{A}-\mathrm{B}) /(\mathrm{E}-\mathrm{F})$ & $\mathrm{EPC}>1$ \\
Koefisien Keuntungan & $\mathrm{PC}>1$ \\
Rasio Subsidi Produsen & $\mathrm{PC}=(\mathrm{A}-\mathrm{B}-\mathrm{C}) /(\mathrm{E}-\mathrm{F}-\mathrm{G}) ; \mathrm{D} / \mathrm{H}$ & $\mathrm{SRP}>0$ \\
\hline
\end{tabular}

Keterangan:

(1) $\mathrm{D}>0$, artinya sistem komoditi tersebut memperoleh keuntungan diatas normal; (2) $\mathrm{H}>0$, artinya indikator keunggulan komparatif atau efisiensi dari sistem komoditi pada kondisi tidak ada divergensi dan penerapan kebijakan yang efisien; (3) I $>0$, artinya adanya transfer dari masyarakat (konsumen) terhadap produsen; (4) $\mathrm{J}>0$, artinya menunjukkan adanya transfer dari petani produsen kepada produsen input tradable; (5) $\mathrm{K}>0$, artinya terdapat transfer dari produsen kepada produsen input non tradable; (6) $\mathrm{L}>0$, artinya menunjukkan adanya tambahan surplus produsen yang disebabkan penerapan kebijakan pada input dan output; (7) $\mathrm{PCR}<1$, artinya sistem produksi usaha tani teh mampu membiayai faktor domestiknya pada harga privat (memiliki keunggulan kompetitif); (8) DRCR $<$, artinya memiliki keunggulan komparatif, (9) NPCO $>1$, artinya kebijakan bersifat protektif terhadap output; (10) NPCI $<$ 1, artinya kebijakan bersifat protektif terhadap input; (11) EPC $>1$, artinya pemerintah menaikkan harga output dan atau input tradable di atas harga efisien; (12) PC $>1$, artinya secara keseluruhan kebijakan pemerintah memberikan insentif kepada produsen; (13) $\mathrm{SRP}>0$, artinya kebijakan pemerintah menyebabkan produsen mengeluarkan biaya produksi lebih kecil dari opportunity cost.

\section{Lampiran 2. Tabel Matrik PAM}

\begin{tabular}{|c|c|c|c|c|}
\hline & \multirow{2}{*}{$\begin{array}{c}\text { Penerimaan } \\
\text { (Rp) }\end{array}$} & \multicolumn{2}{|c|}{ Biaya (Rp) } & \multirow{2}{*}{$\begin{array}{l}\text { Keuntungan } \\
\text { (Rp) }\end{array}$} \\
\hline & & $\begin{array}{c}\text { Input } \\
\text { Tradable }\end{array}$ & $\begin{array}{c}\text { Faktor } \\
\text { Domestik }\end{array}$ & \\
\hline Privat & 1.590 .857 .428 & 184.976 .346 & 936.077 .245 & 469.803 .837 \\
\hline Sosial & 1.351 .292 .487 & 157.822 .423 & 876.914 .776 & 316.555 .288 \\
\hline Efek Divergensi & 239.564.941 & 27.153 .923 & 59.162 .469 & 153.248 .548 \\
\hline
\end{tabular}


Lampiran 3. Indikator-Indikator Dampak Kebijakan Pemerintah Terhadap Teh Hitam Orthodoks Di PTPN VIII Afdeling Rancabali III.

\begin{tabular}{lr}
\hline \multicolumn{1}{c}{ Indikator } & Nilai \\
\hline Dampak Kebijakan Terhadap Output & Rp. 239.564.941 \\
Transfer Output (TO) & 1,18 \\
Koefisien Proteksi Output Nominal (NPCO) & \\
Dampak Kebijakan Terhadap Input & Rp. 27.153 .923 \\
Transfer Input (TI) & 1,17 \\
Koefisien Proteksi Input Nominal (NPCI) & Rp. 59.162.469 \\
Transfer Faktor (TF) & Rp. 153.248 .548 \\
Dampak Kebijakan Terhadap Input-Output & 1,18 \\
Transfer Bersih (TB) & 0,11 \\
Koefisien Proteksi Efektif (EPC) & 1,48 \\
Rasio Subsidi Produsen (SRP) & \\
Koefisien Keuntungan (PC)
\end{tabular}


Palupi Permata Rahmi, Rr. Heni Kuswanti Suwarsinah dan Ratna Winandi 